\title{
Hungarians in the Spanish Legion?
}

\section{Węgrzy w Legionie Hiszpańskim?}

\author{
János Besenyő*
}

\begin{abstract}
The research was conducted on the activities of Hungarian emigrants in the Spanish Legion. It was assumed that the Hungarians provided an important manpower supply for the Spanish Legion and the Spanish army, including in the Spanish Civil War. Examining the facts, it can be concluded that the Hungarian soldiers' participation in the earlier North African wars and the Spanish conflicts had an important effect on the area's geopolitical situation, and it is possible to assume that veterans played a relevant role in the ongoing military and intelligence war between the West and the East.
\end{abstract}

Key words: Spanish Sahara, Spanish Legion, Hungarian Royal Gendarme Veterans' Association, Rif War, Western Sahara.

\begin{abstract}
Abstrakt
Badania, jakie przeprowadzono, dotyczyły działalności emigrantów węgierskich w Legionie Hiszpańskim. Założono, że Węgrzy zapewnili znaczne zasoby ludzkie dla Legionu Hiszpańskiego i armii hiszpańskiej, głównie podczas hiszpańskiej wojny domowej. Analizując fakty, można stwierdzić, że udział żołnierzy węgierskich we wcześniejszych wojnach na terenie Afryki Północnej i w hiszpańskich konfliktach zbrojnych miał istotny wpływ na sytuację geopolityczną tego obszaru. Można również przyjąć, że weterani odegrali istotną rolę $\mathrm{w}$ trwającej wojnie militarnej i wywiadowczej między Zachodem a Wschodem.
\end{abstract}

Słowa kluczowe: Sahara Hiszpańska, Legion Hiszpański, Węgierskie Królewskie Stowarzyszenie Kombatantów Żandarmerii, wojna hiszpańsko-marokańska, Sahara Zachodnia

* Doctoral School for Safety and Security Sciences, Óbuda University, Hungary; (e-mail: besenyo.janos@phd.uni-obuda.hu); iD https://orcid.org/0000-0001-7198-9328. 


\section{The Legion}

The creation of the Spanish Legion (Tercio de Extranjeros) ${ }^{1}$ was already decided on in 1919 by the Spanish military leadership, but it was ordered only on 28 January 1920 by a royal decree of the ruling king, Alfonso XII. ${ }^{2}$ The plan was that the badly performing, poorly trained, heavy loss-suffering, mainly conscripted corps fighting on the African front should be replaced by "official", well-trained soldiers. ${ }^{3}$ They hoped that this military unit created in the French style would be at least as successful as its model, the French Foreign Legion. The Legion came under the supervision of the then Minister of War, José Villalba Riquelme, and Lieutenant Colonel José Millán-Astray Terrenos was appointed as its first commander, who started in that same year with the creation of the first battalion (bandera) in Ceuta. Although some of the Spanish Chiefs of the Defense High Command and the officers serving in the motherland was against the establishment of the Legion, the new commander was not disturbed by this, and being aware of the solid royal support he created 4 further battalions, ${ }^{4}$ which were filled out mainly with Spaniards originating from the earlier Latin-American Spanish colonies (for example Cuba) and in a smaller degree with foreign citizens as well. ${ }^{5}$ The battalions were composed of a command company, two infantry companies and a machine-gun company. The Legion's first base was

${ }^{1}$ The Tercio was the war formation of the Spanish infantry from the second third of the 16th century to the middle of the 17 th century. The use of the word "third" comes from the meaning that it represented the third of the all-time Spanish infantry. The Tercio's significance lies in that it was the first military organization that combined spears/pikes and firearms in one corps in the infantry. The tercio - as a separate tactical unit - represented roughly the power of one regiment (3000 men). It was divided into 10 companies, of which 8 consisted of 200 pikemen, 100 arquebusiers (infantrymen using a smaller bore firearm than a musketeer) and 20 musketeers. This kind of unit secured for almost a century the invincibility of the Spanish infantry. J. Szabó: Hadtudományi lexicon. Budapest 1995, p. 1319.

2 The predecessor of the Spanish Legion - which was called by the same name - was established on 28 June 1835 from the soldiers transferred by the French government from the French Foreign Legion. The unit's main task was to support Isabella II of Spain in the First Carlist War. The Legion - which fulfilled its duty and suffered great losses — was disbanded on 8 December 1938.

3 J.E. Alvarez: The Betrothed of Death. The Spanish Foreign Legion During the Rif Rebellion, 1920-1927. Westport CT 2001, p. 13.

${ }^{4}$ Until 1921 the Legion consisted of only 3 battalions, yet because of the Rif War, during which it was the Legion that won almost the only victories, it was given the opportunity to create 2 more battalions. J.E. Alvarez: The Betrothed..., p. 59.

5 The first 200 men accepted into the Legion's ranks were persons of mainly Spanish and also early Spanish colonial origin (Latin-America, the Philippines, etc.). The foreigners were represented by one Chinese, 3 Japanese, a Russian prince, a German, an Austrian, an Italian, 2 French, 4 Portuguese, a Maltese, a Belgian and an African American from New York. J.E. Alvarez: The Betrothed..., p. 19. 
formed in Ceuta, because the primary fields of the organization's deployment were the Spanish African territories, and its first mission was in Spanish NorthAfrica, in the Rif War (1920-1926). This war was fought in what was then Spanish Morocco: under the leadership of Abd el-Krim, the Rif tribes revolted against the Spanish colonizers, and they proclaimed their own state. This the Spanish couldn't tolerate, and they dispatched their corps against the Berbers. A cruel war broke out between the two forces.

For their valor in combat, the Legion gained the name Moroccan Tercio (Tercio de Marruecos); nevertheless, after the Rif War they were only referred to as the Tercio. At that time they were one of the best trained, best equipped, best supplied and most renowned units of the Spanish Army. ${ }^{6}$ The world got to know at this time the name of the later Spanish president, Franco Bahamonda, who himself took part in the creation of the Legion, and as the commander of the first battalion he participated in almost all the battles of the 1923-1927 war, and had personally a hand in the defeat of Abd el-Krim. ${ }^{7}$ The legionnaires acquired their better-known name during the Spanish Civil War (1937); since then everybody has called them the Spanish Legion or Spanish Foreign Legion. At that time the organization already consisted of 18 battalions and a further 3 auxiliary units - armored, sapper and special operations. One of the most renowned leaders of the Legion was the later dictator Francisco Franco, who was the commander of the first battalion, and who later became second-in-command of the entire corps. His unit - with the help of the Spanish-friendly Moroccan tribesmen's units (Fuerzas Regulares Indígenas) - fought throughout the Rif War, in which they won an outstanding reputation as soldiers who were loyal to the end to their officers, and who followed orders under any circumstances. This is the reason why their units were sent to suppress the Asturian Miners' Strike of 1934 (October) instead of units of the regular Spanish Army, many of whose soldiers sympathized with the miners. ${ }^{8}$

The Legion under the leadership of Lieutenant Colonel Juan Yagüe played a large part in the Spanish Civil War, where they fought on the side of the anti-republican general, Francisco Franco, with the Moroccan units. The Legion units were the most trained, real wartime-experienced troops of the Spanish Army joined to the putschists' side, and achieved significant results against the regular, conscripted soldiers. With their help, the rebels could gain a foothold first on the African continent, then in the motherland as well, and in fact they conquered more and more areas from the republican forces. During the Civil War the unit suffered serious losses in relation to its size. Among the legion-

6 J.E. Alvarez: The Betrothed..., p. 166.

7 Th.P. Anderson: The French Intelligentsia and the Spanish Civil War, 1936-1939. Dissertations. Chicago 1965, p. 12.

8 J.E. Alvarez: The Betrothed..., p. 223. 
naires 7,671 were killed, 776 went missing and 29,000 were wounded. These losses are even greater considering that the Legion never fielded more than 10,800 soldiers at one time. In the Civil War, which lasted almost 3 years, the Legion's enlistment changed completely 4 times. For example, the 4th battalion of the 13th division, with its 600 fighting soldiers, suffered altogether 10,000 losses, which meant that it had to be reorganized 17 times. The legionnaires accounted for $12.5 \%$ of the nationalist side's total casualties. ${ }^{9}$ Despite this, after Franco's victory the Legion's numbers were significantly reduced and the remaining units were sent back to their barracks in Africa. The Legion henceforth consisted of 4 tercios (regiments), and their organization became more or less the same as it is today.

In the Second World War, many units of the Legion fought in the ranks of the "Blue Division", which was lent to the Germans, where it could gain more military experience. After the Second World War came the hard lesson. Although the Spanish were exempt from prosecution for their neutrality, the Francoist regime was quarantined, and it started to lose its African colonies one by one. First it lost Spanish Morocco in 1956, so the troops stationed there went to Ifni, Ceuta and Mellila, as well as to Spanish Sahara. In the following years the soldiers of the Legion took part in every local battle until the withdrawal of the Spanish in 1976. There had been conscription into the infantry of the corps from the Sahrawi tribes, but their proportion reached only a few percent. The training and the equipment of the units was very good, and in its battle order there were French AMX-30 and AML-90 type medium tanks and some units deployed Heinkel 111 bombers along with camel fighters. The third tercio of the Legion was stationed in El-Aaiun, while the fourth tercio was in Villa Cisneros. ${ }^{10}$

In "The Forgotten War" (1957-1958) the Moroccans attacked Ifni, which the Legion's units successfully defended with the help of the local auxiliary forces, but despite this the enclave was given to the Moroccans. Thereafter, the units of the Legion were reassigned to Spanish Sahara, where they were reorganized and reinforced.

However, they were not able to rest here, because the Sahrawis also wanted an independent state, and in 1967 they created their own political movement, the Saharan Liberation Organization (Harakat Tahrir saguia el-Hamra wa Oued ed-Dahab), ${ }^{11}$ whose first leader was Mohamed Sidi Ibrahim Bassiri. Although the organization wanted to achieve independence by peaceful means, soon a bloody battle took place between them and the Legion's units. Shortly after -

9 "Magyar Katonai Szemle" 1940, 10/2, nr 5, p. 561-562.

10 J. BESENYő: A nyugat-szaharai válság egy magyar békefenntartó szemével. Pécs 2012, p. 64.

11 S.C. Saxena: Western Sahara, No Alternative to Armed Struggle. Delhi 1995, p. 113 114; S. Zunes, J. Mundy: Western Sahara. War, Nationalism and Conflict Irresolution. Syracuse 2010, p. 103. 
on 10 May 1973 - the Sahrawis formed the Polisario (Frente Popular para la Liberacion de Saguia El-Hamra y Rio de Oro) with the aim of the total liberation of Western Sahara. ${ }^{12}$ The new movement carried out its first action 10 days later, on 20 May, when its members attacked the Spanish military checkpoint in El-Khanga. ${ }^{13}$ In short order they executed other attacks against smaller military installations including Mahbas, Echderia, Bir Lehmar, Tifariti, Hauza, Amgala and Guelta Zemmour, and they also assaulted the phosphate mines in Bou Craa, where they damaged the phosphate-carrying facilities linking these barracks to the port. At that time, the Spanish thought of Western Sahara as their own, and they mobilized the units of the military to settle matters with the new armed group. In May 1974 they began the "Barrido" operation (Operacion Barrido), during which they deployed military helicopters beside the Policia Territorial and the Tropas Nomadas against the Polisario's militants. Whilst the organization suffered heavy losses, it couldn't be eliminated; in fact, more and more Sahrawis joined it, among whom were many who had served in the Legion or in the Spanish military, as well as in the police organizations composed of locals. Yet not only the Sahrawis, but also Morocco and Mauritania laid claim to the area of Spanish Sahara, which the Spanish - who were unable to hold on to the colony - gave to the two neighboring countries, which resulted in a war that lasted until 1990 (and which hasn't fully ended even today) between the natives, Mauritania ${ }^{14}$ and Morocco. Finally, the units of the Legion were entirely withdrawn from Western Sahara in 1976, and the larger part of the troops were restationed on the Canary Islands. With this the organization's active service largely ended, though smaller units remained in Ceuta and Mellila. In 1987 the Legion was reshaped, so that foreigners (except for the Spanish speaking citizens of former colonies) were not allowed to serve in it anymore. In 2001 foreigners could sign up again in the Legion. ${ }^{15}$

12 Their founders named the organization at first "Frelisario", but they changed their name soon to "Polisario".

13 D.L. Price: Morocco and the Sahara. Conflict and Development. "Conflict Studies" 1977, no 88, p. 5-6.

${ }_{14}$ Mauritania was defeated by the natives and in 1978, she made peace by relinquishing all of her territorial claims. T. Hodges: Western Sahara, The Roots of a Desert War. Westport CT 1983, p. 267-276.

${ }^{15}$ H. Driessen, W. Jansen: Staging Hyper-masculinity on Maundy Thursday. Christ of the Good Death, the Legion and Changing Gender Practices in Spain. "Exchange" 2013, No 42, p. 86-106. 


\section{Hungarian volunteers in the Legion}

Although most Hungarians who signed up to foreign military duty joined the French Foreign Legion, quite a few tried their luck in the Spanish Legion as well, though a lot less data is available about them than about those serving in the French Foreign Legion.

Among the first Hungarian legionnaires was Lajos Matuss, who couldn't find any work close to home, so he tried his luck abroad. Since it wasn't easier to get employment anywhere, he went to the Spanish Legion's recruitment office. Matuss got into the Legion because of bread-and-butter worries and he served in the fortress of Ceuta and took part in the battles against the Rif military leader, Abd el-Krim. ${ }^{16}$

At that time also serving in the Legion was Lajos Imerle from Esztergom, who went into the hell of the First World War from the desks of the Trainingcollege. First, he served as an ensign, then as a first lieutenant, when he was taken prisoner by the Russians and was deported to Siberia, from where he got home with great difficulty. At home he didn't find a place and soon he volunteered for the Legion, where he began service as a regular soldier, then after only three years attained the highest non-commissioned officer rank (sub-lieutenant). In his course of service he received several recognitions and decorations, and after his enlistment expired he joined another corps and served in the Spanish gendarmerie in Tétouan. ${ }^{17}$

The Hungarian state news agency (Hungarian Telegraph Bureau - abbreviated as MTI) prepared an account on another legionnaire, Jenő Jakus. ${ }^{18}$ Jakus carried on a communist propaganda campaign in the villages near Szeged, so he came to the attention of the police. According to the document for his role in the 1919 communist events, he was sentenced to 10 years of prison time, which he began serving in the Hungarian Prison in Szeged (the so-called "Csillag-

${ }^{16}$ Hungarians fought not only in the Spanish Legion but also in the army of Abd el-Krim as deserters, thus the Hungarians could even face each other on the battlefield. D. SASSE: Franzosen, Briten und Deutsche im Rifkrieg 1921-1926, Spekulanten und Sympathisanten, Deserteure und Hasardeure im Dienste Abdelkrims. München 2006, p. 90, 104, 110. The former Hungarian first lieutenant Sándor Sáski fled to the Arab rebels: Géza Paksy, frigatelieutenant can't commission his West-African flying company because of the Rifqabil-wars. "Kis Újság”, 30 May 1934, p. 7, "Kis Újság”, 29 September 1925, p. 5.

${ }^{17}$ Imerle Lajos magyar tanitó spanyol csendör Afrikában. "Pesti Napló", 16 September 1928, Sunday Issue, p. 35.

18 "Magyar Távirati Iroda", 15th broadcast, 30 July 1931, 13 hours 35 minutes - https:// library.hungaricana.hu/hu/view/KulfBelfHirek_1945_11_1_001-123/?pg=411\&layout=s\&qu ery=1degenl\%C3\%A9g1\%C3\%B3 (accessed: 5.08.2017). To the same case also relates: "Friss Ujság", 31 July 1931, p. 8, the "Budapesti Hírlap", 31 July 1931, p. 4, and the "Népszava", 31 July 1931, p. 12. 
börtön”), but he successfully escaped, then emigrated from the country. Firstly, he served in the French Foreign Legion, then from there relocated to the Spanish Legion, from which he was ,discharged". After that he stayed in France, then returned to Hungary, where he came again to the attention of the police, because he applauded the Hungarian Soviet Republic, and verbally abused the ruling government. The policemen caught him, but he escaped from custody, was captured only a few days later, and imprisoned again.

In 1926 József Bakay Smolka entered the Legion, first serving in Mellila. He was first promoted to the rank of lance-corporal, then in 1930 he became sergeant. In the Civil War, like most of the legionnaires, he fought on the side of Franco. On the 11 August 1936 Extremadura Operation his battalion achieved outstanding results, in which he personally played a huge role. In November 1936, at the Siege of Alcazár, and again not much later at Madrid, he was slightly injured. In recognition of his merits, he received a decoration. A few days later he was again injured, and during his hospitalization he was promoted to the rank of ensign. In 1937, he was ordered to the headquarters of the 2nd Legion as an acknowledgement for his endurance on the fronts of Andalusia and Extremadura. In 1946, he was still in the Legion, when in recognition of his continuous duty for 15 years Franco awarded him 1,500 pesetas. ${ }^{19}$

Again, at the time of the Civil War several Hungarians served in the Legion. One of them was Tibor Liszbon, about whom we know only that he was promoted to the rank of sergeant in April, 1937 and lost his life during the War. József Borsica Isermann had a very adventurous life. Barely aged 22 he joined the Spanish Navy, from which he resigned in 1928 after 4 years of service. However, civil life was not for him, so in 1931 he entered the Legion. On 28 September 1936 at the Battle of Peraleda de la Mata he stood his ground, so they promoted him to the rank of lance-corporal; then in August 1938 he became a sergeant of the IVth Battalion. At the time of the Civil War Pál Seszták from Nyíregyháza served in the Legion as well. He had been unable to find work as a tailor at home, so he emigrated to Spain. Since he couldn't find a workplace, in 1934 he tried his fortune in the Legion, where he attained the rank of sergeant, then in the Spanish Civil War he fought on the side of Franco against the republicans. In his unit he served with another Hungarian, János Szmolár form Békéscsaba, who also received non-commissioned officer rank..$^{20}$ Gyula Gunda was a flight first lieutenant, who, after graduating from the Ludovika Military Academy, became an officer in the Royal Hungarian Army; he served first at

19 "Diario Oficial, del Ministerio del Ejercito" 1946, Ano LVII. Num. 34, Sábado, 9 de febrero, de, Tomo I.Pág.529 - http://www.bibliotecavirtualdefensa.es/BVMDefensa/i18n/ catalogo_imagenes/imagen.cmd?path=26500\&posicion=1 (accessed: 5.08.2017).

"Nyirvidek - Szabolcs1 Hirlap", 4 August 1936, p. 3 - https://library.hungarica na.hu/hu/view/Nyirvidek_1936_08/?pg=18\&layout=s\&query=Spanyol\%20Idegenl\%C3\% A9gi\%C3\%B3 (accessed: 6.08 .2017$)$. 
the Sopron Garrison, and later at the Szombathely Aviation Branch, then at the outbreak of the Spanish Civil War he asked to be discharged, and served on the side of Franco against the republican forces. In the war he won a lot of air victories, although he was injured a few times. For example, in an air battle above Madrid he had to execute a forced landing during which he broke his arm; again in 1938, near the heavy fighting at Tereuel, his warplane was shot down, and he only survived the crash with serious injuries. ${ }^{21}$

Interestingly, between the two World Wars many articles were published not just about the French Foreign Legion, but also about the Spanish Legion, and because of that a lot of people regarded the Legion as an opportunity - or a last opportunity. For example, three students tried to escape from Budapest and join the Legion. However, their tour ended at Székesfehérvár, from where the local police took them home. ${ }^{22}$

After the Second World War, many Hungarians fled to Spain, ${ }^{23}$ where the Spanish Foreign Legion welcomed them as it did allied Germans soldiers. Most of them tried to change their names, so we don't know anything about most of them, though there were those who served in the Legion under their own names. Among the latter was the Debrecen-born Ádám Horváth, who was in the Legion for more than a year. According to his account published in the "Új Dunántúl" periodical in 1946, some Arrow Cross officers had recruited Hungarians to the Spanish Legion at Munich. It mentions by name one of the members of the recruiting "Legionist Commission", Arrow Cross Captain László Fehérváry. The volunteer-legionnaire Horváth was transported with his 30 companions through France to Spain, then to Morocco. According to his account in the Moroccan camp he already met several Hungarians, and he was put in a separate Hungarian unit, which was led by Alfred Erichson, a German staff-officer. A few of the Hungarians went to fight in Greece against the communists. Horváth met with men from Budapest, Transylvania and the Great Hungarian Plain, and according to his account, some other men had recently arrived from the displaced persons camp of Weidmannsdorf, which was located near to Klagenfurt. Malaria broke out amongst them, but their number didn't decrease, since reinforcements flew in week after week. There was also a Hungarian language newspaper printed at the training facility, which reported on the Hungarian situation. According to an article from 1947, the Emigré Hungarians' Republican League took over recruitment into the Legion. ${ }^{24}$

${ }^{21}$ Magyar repülőtiszt hösi halála a spanyol fronton. "Kis Újság”, 9 February 1938, Wednesday Issue, p. 5, and: Magyar pilótatisztet löttek le a spanyol vörösök. "Makói Újság", 10 February 1938, p. 3.

22 "Budapesti Hírlap", 21 Februray 1939, Tuesday Issue, p. 8.

${ }^{23}$ Á. ANDERle: A magyar-spanyol kapcsolatok ezer éve, in: Iberoamericana Quinqueecclesiensis 3, Pécsi Tudományegyetem Ibero-Amerika Központ, Pécs 2005, p. 21 — http:// Www.idi.btk.pte.hu/dokumentumok/ibero2005.pdf(accessed: 12.08.2017).

"Uj Dunántúl", 238, No IV, 10 October 1947, Sunday Issue, p. 2. 
Attila Darvas Tóth joined the organization in 1974, and served in Spanish Sahara. ${ }^{25}$ The Hungarian legionnaire arrived from Veszprém and after he joined the Legion, he found himself in the Western Saharan areas, where he was involved in a fight not only with the militants of the Polisario but with the Moroccan soldiers infiltrating the area as well. According to his narrative, between 1958 and 1986 more foreigners served in the Legion, which was partly because the French Foreign Legion rejected previously convicted or wanted persons, so these often went to the Spanish, who welcomed every volunteer to their desert wars (Ifni, Western Sahara) where they were experiencing considerable casualties. However, after the death of Franco (1975) the number of foreign recruits started to decline, and then in 1986 - after the Spanish Ministry of Defense reduced the effective force and reshaped the organization - fell to zero.

Attila Darvas Tóth signed up during the most chaotic time of the Legion, when the legionnaires fought lesser and greater battles every day with the guerillas of the Polisario. The platoon to which he was dispatched as a recruit didn't have a non-commissioned officer in command, since their sergeant had lost his life in a battle at the Mauritanian frontier in December 1974, and the Legion couldn't find a replacement for several months. During Tóth's tour of duty he met with a legionnaire from Kecskemét who worked on a ship, and deserted to Canada with a Hungarian non-commissioned officer from Pest. He knew about another legionnaire, who was a physician, and who after serving his time went to Rhodesia. Besides these stories Tóth heard about other Hungarian legionnaires, but hadn't met them. According to him the Spanish gave the ranks of non-commissioned officers readily to the Eastern Europeans, but they couldn't receive an officer's comminssion.

After his training he got to Ceuta, where he was continuously on guard duty, and from where they took him every three months for four weeks on road patrol to the Western Saharan desert. By that time, he had learned that the Spanish didn't like or respect the Legion, but regarded it as a useful tool for tasks where great losses could be expected. He thought that the most difficult time was those seven months after Franco died (20 November 1975), and the Spanish decided that they would give Western Sahara to Morocco and Mauritania. Although the Spanish population and the members of the public administration had left the area by the end of 1975, the soldiers of the Legion stayed another two months. They didn't have any station, or dispatched any patrol, which wasn't attacked, a lot of times by those Sahrawis who had served previously in the nomad units (Tropas Nomadas) created by the Spanish, and who had changed sides to the Polisario. The Hungarian legionnaire lived to see that the Legion's leaving the Sahara became unnecessary for the Spanish government, how the previously powerful unit lost morale, how its members commited criminal offenses, and af-

\footnotetext{
25 "AGMAV", C.46789, Cp. 30.
} 
ter that how the soldiers of the Legion were forced to leave the organization. He himself was discharged in $1984 .{ }^{26}$ It seems appropriate that Hungarians served in the Legion even after him, though they could have left the corps possibly after the removal of the foreigners - for example Attila Szászvári, who signed up in 1977.

The legionnaires discussed up to this point joined the Legion voluntarily. However, there was a course, which continued for years, in which Spain and the Fraternal Community of Hungarian Fighters gathered migrant soldiers, gendarmes (former Horthyst officers), and sent them in outmost secrecy for a one year "group training" to the Spanish Legion, so that they could refresh their faded military knowledge, and could learn new fighting techniques. Before this paper discusses the details of this program, I would like to introduce the Fraternal Community of Hungarian Fighters.

\section{Fraternal Community of Hungarian Fighters}

The Soldiers' Fraternal Community, built up as a military organization and consisting mainly of soldiers, was founded in the Summer of 1948 by major-general Ferenc Adonyi-Naredy in Klagenfurt, and it was later renamed to Fraternal Community of Hungarian Fighters (MHBK). However, the official founding of the MHBK took place only on 1 January $1949 .{ }^{27}$ The organization was headquartered until 1955 in Austria, in the town of Absam, and then moved to Munich. The first leader of the organization was major-general András Zákó, who filled this post until his death in 1968. The largest groups of the organization operated in Austria and Germany, but eventually in all of the Western European countries; in fact, after the beginning of their emigration they formed units in North and South America, too. Thus, at the beginning of the 1950s the MHBK was present in 23 countries with 31 groups consisting of tens of thousands of members. ${ }^{28}$ The organization consisted of divisions and subdivisions. Its membership consisted mostly of Horthy's officers or non-commissioned officers who had emigrated after the Second World War; only some of them came from other law enforcement

${ }^{26}$ Volt egyszer egy Spanyol Idegenlégió I, "Nagypolitika.hu" - https://nagypolitika. hu/2016/02/22/volt-egyszer-egy-spanyol-idegenlegio-i/ $\neg$ (accessed: 6.08.2017), and: Volt egyszer egy Spanyol Idegenlégió II, "Nagypolitika.hu" - https://nagypolitika.hu/2016/08/11 volt-egyszer-egy-spanyol-idegenlegio-ii/(accessed: 6.08.2017).

"T. Borband: A magyar emigractó életrajza 1945-1985. Bern 1985, p. 26-27.

${ }^{28}$ M. BARÁTH: Támogatni vagy bomlasztani? Adalékok a magyar hivatalos szervek emigrációs politikájának változásához, "Betekintö", 2011, no 3 - htttp://www.betekinto.hu/sites/ default/files/2011_3_barath.pdf (accessed: 20.08.2017). 
organizations (gendarmerie, police, etc.), and civilians didn't join at all. For this reason, the MHBK considered itself an exclusively military organization. ${ }^{29}$ The Americans thought they were useful against the Soviet and Hungarian Secret Services, and according to some intelligence reports, several officers belonged to the membership, who were formerly active members of the Arrow Cross Party, so the Americans tried continuously to monitor the organization. ${ }^{30}$

The organization officially helped the soldiers living in emigration, however - mostly in the first years - they continued intelligence activity against the communist Hungarian government. They coordinated the gathered information for the American, French and other Western European governments. However, many of the members of the organization worked on their own, and sold their information to other secret services. After a time, they sold irrelevant gossip, for example that collected from refugees, or data created by themselves - several times false facts as well - to the Western intelligence agencies. For this reason the latter handled the data collected by the MHBK with suspicion, and because of its insufficiency (or just falsity) they looked for other sources of information. Because of the aforesaid the CIA had already begun to regard the MHBK as an unreliable organization in $1951,{ }^{31}$ and in fact after it confirmed the organization's unreliability from several sources, they shared this information with other intelligence agencies. ${ }^{32}$ The MHBK's members gathered a lot of information too; they had been united by the Kopjás (literally "pikemen") movement modelled on the Nazi Werewolves in the time of the Arrow Cross Party. The creation of the pikemen was in 1942, but it was only realized in 1944 by General András Zákó and Captain-General Miklós Korponay. The aim of the movement was mainly to commit sabotage actions against the Soviet forces entering the country and they attempted to slow the Russian advance. The movement continued its activities after the war, and in 1949 it merged completely into the Fraternal Community of Hungarian Fighters. Zákó declared to the Westerners that the Kopjás-movement was an effectively functioning resistance organization. But the facts proved other-

${ }^{29}$ G. BorbándI: A magyar emigráció..., p. 26.

${ }^{30}$ Collegial Society of Hungarian Veterans, aka. Comradeship of the Hungarian Warriors, 11/3/50, CIA - https://www.cia.gov/library/readingroom/docs/MAGYAR,\%20HARCOSOK,\%20BAJTARSI,\%20KOZOSSEGE\%20\%20\%20VOL.\%201_0003.pdf- (accessed: 20.08.2017.), as well as: BRIEF about the Comradeship of Hungarian Veterans, DCE 1858, 17 April 1951, CIA - https://www.cia.gov/library/readingroom/docs/MAGYAR\%2C\%20 HARCOSOK\%2C\%20BAJTARSI\%2C\%20KOZOSSEGE\%20\%20\%20VOL.\%201_0014.pdH (accessed: 20.08.2017).

31 WASH 01854, 28 July 1951, CIA — https://archive.org/details/ZAKOANDREAS-0020 (accessed: 20.08.2017), see also: WASH 01864, 29 July 1951, CIA - https://archive.org details/ZAKOANDREAS-0021 (accessed: 20.08.2017).

${ }^{2}$ In greater detalls about this: Central Intelligence Agency: Paper Mills and Fabrication, February 1952 - https://www.cia.gov/library/readingroom/docs/PAPER\%20MILLS\%20 AND\%20FABRICATION_0001.pdf(accessed: 20.08.2017). 
wise. The ÁVH caught 558 pikemen, but they sentenced 286 persons, which questions the real efficiency of the organization. Nevertheless, it was capable at least of retaining the agents of the Hungarian and Soviet intelligence, thus the Americans and their affiliate organizations could operate more effectively. ${ }^{33}$ The MHBK created with its activities such problems for the military officers of the former political system, that the leaders of the Party removed most of them from the army, ${ }^{34}$ which weakened it a lot, since the field officers and officers were replaced by on the one hand politically reliable, but on the other hand militarily untrained comrades. The organization published monthly its own newspaper titled "Hadak Útján" (literally "On the Path of the Wars"), ${ }^{35}$ and several publications, which relate the fate of the Hungarian soldiers in Soviet captivity (White Book), ${ }^{36}$ or the Hungarian deportations (Black Book), and also published other uncomfortable themes for the Hungarian communist government. ${ }^{37}$ After the events of 1956, the organization became more and more marginalized. At the time it had already lost the support of the American and French secret services, and later - because of the softening of the Cold War, the different internal conflicts and the death of András Zákó - losing its military nature it started to "civilize": it ended its intelligence activities and became only one of several emigrational organizations. ${ }^{38}$

\section{The MHBK and the Spanish Legion}

One of the publicly declared goals of the MHBK was that in the frame of a Third World War they could expel the communist regime which had forced

33 K. Ungváry: Az MHBK szürke eminenciása: Zákó András és az ellene folytatott állambiztonsági eljárások, in: S. GeBeI, IFJ. I. BERTÉNYI, M.J. RAINER: „...nem leleplezni, hanem megismerni és megérteni”. Tanulmányok a 60 éves Romsics Ignác tiszteletére. Eger 2011, p. 483-498 - h http://tortenelem.uni-eger.hu/public/uploads/romsics60_5542287542c20. pdf (accessed: 20.08.2017); 1. ZSITNYANYI: Egy „titkos háboru” természete - A Magyar Harcosok Bajtársi Közössége tagjaival szemben lefolytatott internálási és büntetöeljárási gyakorlat 1948-1950. "Hadtörténelmi Közlemények" 2002, 115, no 4 - htttp://epa.oszk. hu/00000/00018/00022/pdf/hk4.pdf (accessed: 20.08.2017).

${ }^{4}$ J. PIHURIK: A ,horthysta katonatiszt" mint potenciális kém a Rákosi-korszakban.

"Betekintö", 2004, nr 3 — http://www.betekinto.hu/en/2014_4_pihurik(accessed: 20.08.2017).

${ }^{35}$ G. Borbándi: A magyar emigráció..., p. 28, 38, 113 .

${ }^{36}$ The whole book can be reached at the library of the CIA at the next link - https:// www.cia.gov/library/readingroom/docs/MAGYAR\%2C\%20HARCOSOK\%2C\%20 BAJTARSI\%2C\%20KOZOSSEGE\%20\%20\%20VOL.\%201_0014.pdf (accessed: 20.08.2017).

"G. BORBANDI: A magyar emigrácio..., p. $110-113$.

${ }^{38}$ K. Ungváry: Az MHBK szürke eminenciása..., p. 483-498; G. BorbándI: A magyar emigráció..., p. 264. 
them into emigration, and "reconquer" the country. However, the Western allies had their reasons why they didn't want to arm those previously fighting against them. Instead the leaders of Spain - which became isolated after the Second World War - were seriously occupied with the thought of a war against the Soviet Union and the Eastern Bloc. They thought that from the Hungarian, Czech, Slovakian, Ukrainian, Romanian, Croatian and other nationality refugees with the cooperation of the Spanish Legion they would create international brigades, which would take part in the fight against the communists and the liberation of their countries.

The MHBK had — at the time of its founding — already made good connections with the Spanish authorities thanks to former Colonel-General Jenö Szántay, who was the leader of the MHBK's Spanish organization from 1950. ${ }^{39}$ According to certain information, Major-General Zákó had held negotiations already in that year with the Spanish military and secret service leaders, so that Hungarian military officials could receive additional training, and possibly permanent employment in the units of the Spanish Army. ${ }^{40}$ According to one of the reports of the CIA, some of the Hungarian military officers may have already joined the Spanish Legion by $1950 .{ }^{41}$

The former officers serving in the army of Horthy could receive a one-year "guest-officer exchange-service" opportunity in the Legion. The assignment of the officers was organized by Szántay, but neither of the commanding officers could maintain contact with the embassy, so they wouldn't attract the attention of the Hungarian intelligence. The MHBK also tried to prevent contact between officers from different units; such contact was allowed only among those serving in the same unit. Though usually they signed up for a one-year term of service, there was always opportunity for prolongation. Attention was paid in particular to the officers so they could get to the unit appropriate for their qualifications and branch of service, thus they could refresh and get their knowledge up to date. It seems that not only the soldiers living in Spain could serve in the Spanish units, but the members of the military emigration living in other countries as well. The officers received during their duty a payment equal to that of the Spanish officers, to which payment in kind (accommodation, food) was also added by the Spanish government, but lots of them found it insufficient.

39 The Hungarian Emigration in 1950, June 1, 1950. CIA — https://www.cia.gov/library/ readingroom/docs/ZAKO\%2C\%20ANDREAS_0160.pdf (accessed: 20.08.2017).

${ }^{40}$ The fact of the negotiations was strengthened by the CIA too, which had Zákó as a nazi war-criminal — under surveillance - https://archive.org/details/ZAKOAN DREAS-0153 (accessed: 22.08.2017), see also: 1 June 1950, CIA - h/tps://www.c1a.gov 1brary/readingroom/docs/ZAKO\%2C\%20ANDREAS_0156.pdf (accessed: 22.08.2017).

Operation Venus, Ref: OBBA-5355, II May 1956, CIA - https://www.cia.gov/library/ readingroom/docs/KOZMA\%2C\%20FERENC\%20\%20\%20VOL.\%202_0030.pdf accessed: 22.08.2017). 
By 1955 the Spanish had already taken into consideration, that the international corps could be formed, but despite this they continued the "guest-officer program", and in fact they promised to establish a "symbolic" Hungarian unit. We are aware that in 1956 there was an artillery-lieutenant named Gábor Bethlen in Ceuta, as well as a sapper-lieutenant named Makray and an artillerylieutenant named Bényei (or Bénei) in Barcelona. ${ }^{42}$

In the wake of the Hungarian Revolution of 1956, the Spanish leadership proposed a military intervention in Hungary under the supervision of the UN, but because of the disagreement of the superpowers and the Suez Crisis it couldn't be realized. ${ }^{43}$ Despite this the Spanish continued to uphold their previous friendly relationship with the Hungarian military emigration, and - although in outmost secrecy - they welcomed Hungarian officers further into the units of the Legion. On 23 March 1957 the Hungarian ambassador at that time wrote about one of the volunteers in the following way: "As a guest of the Spanish Army former Royal Flying Lieutenant Kálmán Szeödemeteri Dömötör occupies his previous Hungarian Royal Military rank in a one-year service of combat officerduty in the second regiment (Dar-Riffien, Morocco) of the Spanish Legion. ${ }^{44}$ " After this, Lieut. Dömötör joined the organization of the MHBK, and in 1957 he spent a year in the Legion, but he was also active politically. For example after the events of 1956 - he wrote a letter to Béla Király, who had been living as a refugee in the USA, asking that the revolutionary commission working in America not publish statements condemning the Spanish. Király answered to this letter and asked the lieutenant to prepare for him a report which would give an account of the situation of the Hungarian refugees arriving in Spain. This report was later sent to him by the lieutenant. ${ }^{45}$

The ÁVH had already received information that the MHBK was conducting training activities in Spain, for it ordered its agents to gather as much informa-

42 Ibidem.

43 Á. ANderle: 1956 és a spanyol..., p. 55-62.

${ }^{44}$ Marosi Ferenc levele, 1957. március 23, s. 8-195; Á. Anderle: Marosy-iratok..., s. $140-141$.

${ }^{45}$ Kálmán Dömötör didn't stay with the Spanish after the expiration of his service; he was reassigned to the French Foreign Legion. He fought in Vietnam, and after having received French citizenship, he stayed in France where he became the secretary-general of the MHBK, and also president of the Fraternal Community of the Hungarian Legionnaires until 1990, when he passed away. Interjú Sujánszky Jenövel, a párizsi magyarok október 23-i „,diadalivi” megemlékezéseinek szervezöjével — http://www.nagyimretarsasag.hu/images/ kiadvanyok/oroksegunk_2013.pdf (accessed: 22.08.2017), see also: B. NÓvÉ: "PATRIA NOSTRA" '56-os menekült kamaszok a Francia Idegenlégióban. Eszterházy Károly Föiskola, Történelemtudományi Doktori Iskola, Eger 2016, p. 98 - http://disszertacio.unieszterhazy. hu/17/1/N\%C3\%B3v\%C3\%A9_B\%C3\%A9la_disszert\%C3\%Alc1\%C3\%B3.pdf (accessed: $22.08 .2017)$. 
tion as possible regarding the issue. ${ }^{46}$ They protested several times to the Spanish that they were taking part in activities to overthrow the Hungarian government, and that they were giving weapons training to the Hungarian emigrants, in fact in order to enlist them in the Spanish Army. Nevertheless, the Spanish officially denied that they would have recruited emigrant Hungarians or other nationality emigrants for military units, or that they would plan to merge these into the Spanish Army. ${ }^{47}$ It is true that the plan to create various Hungarian corps occurred in 1955, but it was never realized. In the ÁVH's opinion, by that time 500-600 officers and non-commissioned officers had already been trained in Spain..$^{48}$ One of the officers of the ÁVH, Gábor Füredi, dispatched his subordinate officer to Spain with the cover story that he was being sent by his factory, with machinery-improving intentions, and his primary objective was to gather as much information as possible from Marosi and Szántay about the Spanish training facilities, in which not only Hungarians but also other nationals were trained by the Spanish. ${ }^{49}$ The agent didn't find out anything about these camps, since Marosi was not initiated into the military programs and the one responsible for them - Szántay - was dying. The only information gathered was from Marosi's secretary, Aurél Czilchert, who served in the Legion for one year, which was not enough information for the ÁVH. ${ }^{50}$

In spite of this, the Spanish didn't reject the idea of creating an international army consisting of refugees from the communist countries, which they would have then used against the Soviets. The plan, which can be found under the title of "Lo que debe hacerse en este momento" 51 in the Foreign Policy Archives of Madrid, was probably prepared by general Zákó at the request of the Spanish. The plan suggested the establishment of a Central and Eastern European

${ }^{46}$ Operation Venus, OBBA-4701, 27 January 1956, CIA - https://www.cia.gov/library/ readingroom/docs/KOZMA\%2C\%20FERENC\%20\%20\%20VOL.\%202_0024.pdt, see also: Operation Venus, OBBA 3554, 8 June 1956, ClA - https://www.cia.gov/library/readingroom/ docs/KOZMA\%2C\%20FERENC\%20\%20\%20VOL.\%202_0032.pdf(accessed: 22.08.2017).

Operation Venus, OBBA-3554, 8 June 1956, CIA - https://www.cia.gov/library/read ingroom/docs/KOZMA\%2C\%20FERENC\%20\%20\%20VOL\%202_0032.pdt (accessed: 22.08 .2017 ).

${ }^{48}$ This statement was treated with suspicion by the agent with whom his ÁVH supervising officer (Gábor Füredi) shared this. It is possible that the secret service tried to gather more support from the communist leadership and ensure their position by the enlargement of the information received from them - https://www.cia.gov/library/readingroom/docs/ KOZMA\%2C\%20FERENC\%20\%20\%20VOL.\%202_0001.pdf (accessed: 22.08.2017).

Operation Venus, OBBA-4701, 27 January 1956, CIA - https://www.cia.gov/library/ readingroom/docs/KOZMA\%2C\%20FERENC\%20\%20\%20VOL.\%202_0024.pdt (accessed: 22.08.2017).

${ }_{50}$ Operation Venus, Ref: OBBA-5355, 11 May 1956, CIA — https://www.cia.gov/library/ readingroom/docs/KOZMA\%2C\%20FERENC\%20\%20\%20VOL.\%202_0030.pdf (accessed: 22.08.2017).

51 "What we have to do at this moment." 
military command, which with either a Polish-Baltic or a Southeastern center would have consisted of 5000 Hungarian, Slovakian, Czech, Sudeten German, Romanian, Croatian and Bulgarian units each. According to the plan they would have started the liberation fight with the outbreak of a Czech revolt. The units would have been formed with Spanish support, but also with American material assistance, and the creator of the plan hoped for such material help from the Americans. The scheme - calculating with three years to prepare everything - acknowledged the possibility of a restrained nuclear war. It was written by hand on the assumption that it was supported by the Spanish government, with the condition that the Americans approve of it as well, but only with the leadership of Zákó. Yet another secret item suggested the stricter control and selection of the Hungarian refugees arriving in Spain, and the establishment of a secret financial fund - handled by the government - for operations against the communist countries. ${ }^{52}$ However, by 1957 the Spanish political and military leadership didn't regard these efforts as relevant, and thus the guest-officer programs were terminated from 1958 on.

\section{Conclusion}

At the end of this article it is worthwhile to summarize the facts about the Hungarians and the Spanish Legion. At the beginning, the account focussed on the participation of the Hungarians in the Spanish Saharan and Western Saharan conflicts. It can be concluded that the Hungarians regularly took part in the events of the North-African Saharan wars, for example the Rif Wars. There were several Hungarian officers who fought in those battles. Between the two World Wars and mostly after the Second World War the Hungarians were again present in the area, since the Hungarian military and its soldiers were welcomed by the Spanish and in the Spanish Legion, which was one of the main supports of the Francoist military. The Hungarians who entered the Legion took part also in the Spanish Civil War, where they used their experience to help the nationalists. After the Second World War and the formation of the Eastern Bloc, many former Hungarian soldiers became inconvenient for the new communist regime, and as they were persecuted, many of them emigrated or fled the country hoping to find support against the communist regime. Franco himself had an idea - which he elaborated with one of the Hungarian veterans - to establish an army of Central and Eastern European emigrants, but it was never realized, because of the unfavorable political situation. However, a lot of Hungarian sol-

52 Á. Anderle: 1956 és a spanyol..., p. 60-61. 
diers received hard training in the Spanish Legion, and they were organized in the MHBK. They not only fought in North Africa, but also were recruited by Western and Hungarian secret services, which wanted to use them to gather information about the ongoing activities of the Hungarian emigration. The Hungarian communist secret service (ÁVH), and also the British, American, Belgian and French intelligence services used them to receive data about the former officers' operational work. The very complicated situation ended in 1958, when because they didn't believe that liberation of the Eastern European countries could be achieved - the Spanish relinquished the idea of the common army and the Hungarian officers' "guest-training" ended.

\section{Bibliography}

"AGMAV", C.46789, Cp. 30.

Alvarez J.E.: The Betrothed of Death. The Spanish Foreign Legion During the Rif Rebellion, 1920-1927. Westport CT 2001.

ANDERLE Á.: A magyar-spanyol kapcsolatok ezer éve. „Iberoamericana Quinqueecclesiensis"

3: Pécsi Tudományegyetem Ibero-Amerika Központ. Pécs 2005 —http://www.idi.btk. pte.hu/dokumentumok/ibero2005.pdf (accessed: 12.08.2017).

Anderson Th.P.: The French Intelligentsia and the Spanish Civil War, 1936-1939. Dissertations. Chicago 1965.

BARÁth M.: Támogatni vagy bomlasztani? Adalékok a magyar hivatalos szervek emigrációs politikájának változásához, "Betekintő", 2011, no 3 - http://www. betekinto.hu/sites/default/files/2011_3_barath.pdf (accessed: 20.08.2017).

BESENYö J.: A nyugat-szaharai válság egy magyar békefenntartó szemével. Pécs 2012.

"Betekintő", 2004, nr 3 - http://www.betekinto.hu/en/2014_4_pihurik (accessed: 20.08.2017).

Borbándi G.: A magyar emigráció életrajza 1945-1985. Bern 1985.

BRIEF about the Comradeship of Hungarian Veterans, DCE 1858, 17 April 1951, CIA -https://www.cia.gov/library/readingroom/docs/MAGYAR\%2C\%20HAR COSOK\%2C\%20BAJTARSI\%2C\%20KOZOSSEGE\%20\%20\%20VOL. $\% 20$ 1_0014.pdf(accessed: 20.08.2017).

“Budapesti Hírlap", 31 July 1931.

"Budapesti Hírlap", 21 Februray 1939, Tuesday Issue.

Central Intelligence Agency: Paper Mills and Fabrication, February 1952 — https:// www.cia.gov/library/readingroom/docs/PAPER\%20MILLS\%20AND\%20FAB RICATION_0001.pdf (accessed: 20.08.2017).

Collegial Society of Hungarian Veterans, aka. Comradeship of the Hungarian Warriors, 11/3/50, CIA - https://www.cia.gov/library/readingroom/docs/ 
MAGYAR, \%20HARCOSOK,\%20BAJTARSI,\%20KOZOSSEGE $\% 20 \% 20 \% 20$ VOL.\%201_0003.pdf - (accessed: 20.08.2017).

“Diario Oficial, del Ministerio del Ejercito" 1946, Ano LVII. Num. 34, Sábado, 9 de febrero, de, Tomo I.Pág.529 — http://www.bibliotecavirtualdefensa.es/BVMDefensa/i18n/catalogo_imagenes/imagen.cmd?path=26500\&posicion=1 (accessed: 5.08.2017).

DrIESSEN H., JANSEN W.: Staging Hyper-masculinity on Maundy Thursday. Christ of the Good Death, the Legion and Changing Gender Practices in Spain. "Exchange" 2013, No 42.

"Friss Újság", 31 July 1931.

Hodges T.: Western Sahara, The Roots of a Desert War. Westport CT 1983. https://archive.org/details/ZAKOANDREAS-0153> (accessed: 22.08.2017), https://www.cia.gov/library/readingroom/docs/KOZMA\%2C\%20FERENC\%20\%20 \%20VOL.\%202_0001.pdf (accessed: 22.08.2017).

https://www.cia.gov/library/readingroom/docs/MAGYAR\%2C\%20HARCO SOK\%2C\%20BAJTARSI\%2C\%20KOZOSSEGE\%20\%20\%20VOL.\%201_0014. pdf (accessed: 20.08.2017).

The Hungarian Emigration in 1950, June 1, 1950. CIA - https://www.cia.gov/ library/readingroom/docs/ZAKO\%2C\%20ANDREAS_0160.pdf (accessed: 20.08.2017).

Imerle Lajos magyar tanitó spanyol csendör Afrikában."Pesti Napló", 16 September 1928, Sunday Issue.

Interjú Sujánszky Jenővel, a párizsi magyarok október 23-i,,diadalívi” megemlékezéseinek szervezöjével — http://www.nagyimretarsasag.hu/images/kiadvanyok/oroksegunk_2013.pdf (accessed: 22.08.2017)

"Kis Újság”, 29 September 1925.

“Kis Újság”, 30 May 1934.

“Magyar Katonai Szemle" 1940, 10/2, nr 5.

Magyar pilótatisztet löttek le a spanyol vörösök. "Makói Újság”, 10 February 1938. Magyar repülötiszt hösi halála a spanyol fronton. "Kis Újság”, 9 February 1938, Wednesday Issue.

"Magyar Távirati Iroda", 15th broadcast, 30 July 1931, 13 hours 35 minutes https://library.hungaricana.hu/hu/view/KulfBelfHirek_1945_11_1_001123/?pg $=411$ \&layout $=$ s\&query $=$ idegenl $\% \mathrm{C} 3 \% \mathrm{~A} 9 \mathrm{gi} \% \mathrm{C} 3 \% \mathrm{~B} 3$ (accessed: 5.08.2017).

"Népszava", 31 July 1931.

NóvÉ B.: "PATRIANOSTRA" '56-os menekült kamaszok a Francia Idegenlégióban. Eszterházy Károly Főiskola, Történelemtudományi Doktori Iskola. Eger 2016 http://disszertacio.unieszterhazy.hu/17/1/N\%C3\%B3v\%C3\%A9_B\%C3\%A9la disszert\%C3\%A1ci\%C3\%B3.pdf (accessed: 22.08.2017).

"Nyírvidék - Szabolcsi Hírlap", 4 August 1936 - https://library.hungaricana.hu/hu/view/Nyirvidek_1936_08/?pg=18\&layout=s\&query=Spanyol\%20 Idegen $1 \% \mathrm{C} 3 \% \mathrm{~A} 9 \mathrm{gi} \% \mathrm{C} 3 \% \mathrm{~B} 3$ (accessed: 6.08.2017).

Operation Venus. OBBA-5355, 11 May 1956, CIA - https://www.cia.gov/library/ readingroom/docs/KOZMA\%2C\%20FERENC\%20\%20\%20VOL.\%202_0030. pdf (accessed: 22.08.2017). 
Operation Venus. OBBA-4701, 27 January 1956, CIA -https://www.cia.gov/library/ readingroom /docs/KOZMA\%2C\%20FER ENC\%20\%20\%20VOL.\%202_0024. pdf (accessed: 22.08.2017).

Operation Venus. OBBA-5355, 11 May 1956, CIA - https://www.cia.gov/library/ readingroom/docs/KOZMA\%2C\%20FERENC\%20\%20\%20VOL.\%202_0030. pdf (accessed:22.08.2017).

Operation Venus. OBBA-3554, 8 June 1956, CIA - https://www.cia.gov/library/read ingroom/docs/KOZMA\%2C\%20FERENC\%20\%20\%20VOL.\%202_0032.pdf (accessed: 22.08.2017).

PIHURIK J.: A ,horthysta katonatiszt” mint potenciális kém a Rákosi-korszakban.

Prace D.L.: Morocco and the Sahara. Conflict and Development. "Conflict Studies" 1977, No 88.

Sasse D.: Franzosen, Briten und Deutsche im Rifkrieg 1921-1926, Spekulanten und Sympathisanten, Deserteure und Hasardeure im Dienste Abdelkrims. München 2006.

Saxena S.C.: Western Sahara, No Alternative to Armed Struggle. Delhi 1995.

Szabó J.: Hadtudományi lexicon. Budapest 1995.

"Új Dunántúl", 238, No IV, 10 October 1947, Sunday Issue.

UngVÁRY K.: Az MHBK szürke eminenciása: Zákó András és az ellene folytatott állambiztonsági eljárások. In: „...nem leleplezni, hanem megismerni és megérteni”. Tanulmányok a 60 éves Romsics Ignác tiszteletére. Eds. S. GeBEI, IfJ. I. BERTÉNYI, M.J. RAINER. Eger 2011- http://tortenelem.unieger.hu/public/ uploads/romsics60_5542287542c20.pdf (accessed: 20.08.2017);

Volt egyszer egy Spanyol Idegenlégió I, "Nagypolitika.hu" — https://nagypolitika. hu/2016/02/22/voltegyszer-egy-spanyol-idegenlegio-i/ — (accessed: 6.08.2017).

Volt egyszer egy Spanyol Idegenlégió II, "Nagypolitika.hu” — https://nagypolitika. hu/2016/08/11/volt-egyszer-egyspanyol-idegenlegio-ii/ (accessed: 6.08.2017).

WASH 01854, 28 July 1951, CIA — https://archive.org/details/ZAKOANDREAS-0020 (accessed: 20.08.2017).

WASH 01864, 29 July 1951, CIA — https://archive.org/details/ZAKOANDREAS-0021 (accessed: 20.08.2017).

Zsitnyányi I.: Egy „titkos háború” természete - A Magyar

Harcosok Bajtársi Közössége tagjaival szemben lefolytatott internálási és bün tetöeljárásigyakorlat 1948-1950. "Hadtörténelmi Közlemények” 2002, 115, no 4 - http://epa.oszk.hu/00000/00018/00022/pdf/hk4.pdf (accessed: 20.08.2017).

Zunes S., Mundy J.: Western Sahara. War, Nationalism and Conflict Irresolution. Syracuse 2010 .

János Besenyő had more than 31 years of experience in the Hungarian Armed Forces. In his last assignment as colonel he led the General Staff, Scientific Research Centre more than 4 years. He is an assistant professor of University of Obudai and teaching African history, European security and defence, and conflict man- 
agement. He is a lecturer in National Public Service University, Budapest (Doctoral School of Military Sciences), Eötvös Loránd University, Budapest (Doctoral School of History) and Eszterházy Károly University of Applied Sciences, Eger (Doctoral School of History) about African History, African conflicts, Hungarian participation in African peace operations, Western Sahara, terrorism, migration, Christian-Muslim relations, Hungarian-A frican relations. 